\section{Alternatives to Shellac Coatings Provide Comparable Gloss, Internal Gas Modification, and Quality for 'Delicious' Apple Fruit}

\author{
Jinhe Bai, Elizabeth A. Baldwin ${ }^{1}$, and Robert H. Hagenmaier \\ U.S. Department of Agriculture, Agricultural Research Service, Citrus \& \\ Subtropical Products Research Laboratory, 600Avenue S, NW, Winter Haven, \\ FL 33881
}

Additional index words. Malus $\times$ domestica, shiny, firmness, modified atmosphere, volatile

\begin{abstract}
Zein, starch, polyvinyl acetate (PVA), carnauba, and carnauba-polysaccharide (CPS) coatings were compared with a commercial shellac coating using controlled atmosphere stored 'Delicious' apples (Malus $\times$ domestica Borkh). Coated apples were stored in air at $2{ }^{\circ} \mathrm{C}$ for 2 weeks and then removed to $21^{\circ} \mathrm{C}$ for an additional two weeks to simulate marketing conditions. Gloss, internal $\mathrm{O}_{2}$ and $\mathrm{CO}_{2}$ partial pressures, weight loss, flesh firmness, and contents of sugars, acids and volatiles were measured on 0,2 , and 4 weeks after coating treatment. Starch- and carnauba-coated apples had high initial gloss, similar to that found for shellac-coated fruit. Gloss of all coated fruit decreased similarly during the 4-week evaluation period, although all of the coated fruit were glossier than uncoated controls. For uncoated apples, the differences of $\mathrm{O}_{2}$ and $\mathrm{CO}_{2}$ partial pressure between internal and ambient atmosphere were $\approx 1 \mathrm{kPa}$ at $2{ }^{\circ} \mathrm{C}$, and these increased by a further $2 \mathrm{kPa}$ after transfer to $21^{\circ} \mathrm{C}$. Fruit coated with shellac and starch had $>10 \mathrm{kPa} \mathrm{CO}$, and $<10 \mathrm{kPa} \mathrm{O}_{2}$ at $21^{\circ} \mathrm{C}$. Zein-, PVA- and carnauba-coated apples showed a less modified internal atmosphere $\left(6-7 \mathrm{kPa} \mathrm{CO}, 11-15 \mathrm{kPaO}_{2}\right)$. Internal partial pressures of $\mathrm{O}_{2}$ and $\mathrm{CO}_{2}$ were inversely related for most coatings, except for the CPS coating, for which partial pressures of both $\mathrm{CO}_{2}$ and $\mathrm{O}_{2}$ were low. Carnauba-, PVA-, and shellac-coated fruit lost less weight than uncoated fruit. Starch-, shellac-, and CPS-coated fruit were firmer than those from other coating treatments, and all coated fruit were firmer than uncoated control. Titratable acidity was higher in the fruit coated with CPS, starch, and shellac than in uncoated control. Ethyl alcohol and ethyl esters accumulated in starch-, shellac-, and CPS-coated fruit kept at $2{ }^{\circ} \mathrm{C}$, but, levels of these volatiles decreased after transfer of fruit to $21^{\circ} \mathrm{C}$. Carnauba, PVA and zein coatings compared favorably to shellac for gloss and other quality characteristics.
\end{abstract}

Most 'Delicious' apples marketed in the United States are coated with shellac or a mixture of shellac and carnauba wax. Shellac has a problem with discoloration (whitening) (Baldwin, 1994; Hagenmaier and Shaw, 1992) which limits marketability, and is sometimes associated with nonfood uses. The latter point might some day be viewed negatively by consumers; therefore, it would seem prudent to develop alternative coatings. Furthermore, shellac is currently not listed as "generally recognized as safe" (GRAS) by the U.S. Food and Drug Administration (FDA).

High gloss is considered by the industry to be beneficial for red apple sales. Recently, it has become common to see high gloss coat-

Received for publication 3 Apr. 2001. Accepted for publication 5 Sept. 2001. Mention of a trademark or proprietary product is for identification only and does not imply a guarantee or warranty from the U.S. Dept. of Agriculture. The U.S. Dept. of Agriculture prohibits discrimination in all its programs and activities on the basis of race, color, nationa origin, gender, religion, age, disability, political beliefs, sexual orientation, and marital or family status.

${ }^{1}$ To whom reprint requests should be addressed. E-mail address: ebaldwin@citrus.usda.gov ings on green apples as well. Reducing water loss and respiration rate also helps extend shelf-life of apples previously held in controlled atmosphere (CA) or air. Coatings affect the internal atmosphere of fruit and, therefore, also can potentially reduce the respiration rate. Internal $\mathrm{O}_{2}$ and $\mathrm{CO}_{2}$ partial pressures of uncoated 'Delicious' apples at ambient temperature were $17-20 \mathrm{kPa}$ and $2-4 \mathrm{kPa}$ Bai et al., 1990). Coatings cause an increase in internal $\mathrm{CO}_{2}$ and a decrease in $\mathrm{O}_{2}$ partial pressures because of fruit respiration, in a manner similar to modified atmosphere (MA) packaging. Shellac coating on 'Delicious' apples raised internal $\mathrm{CO}_{2}$ to $\approx 10 \mathrm{kPa}$, and reduced $\mathrm{O}_{2}$ to $\approx 9 \mathrm{kPa}$ at ambient temperature, and led to ethanol accumulation of $\approx 10$ times that of uncoated control (Alleyne and Hagenmaier, 2000). The gas changes caused by shellac coatings were moderated by adding carnauba flavor was induced in 'Starking Delicious' apples stored in MA packaging at $8{ }^{\circ} \mathrm{C}$, with 6 $\mathrm{kPa} \mathrm{CO}_{2}$ and 7-9 $\mathrm{kPa} \mathrm{O}_{2}$ partial pressure in the package (Ueda et al., 1993). Assuming an additional gradient of $1-3 \mathrm{kPa} \mathrm{O}_{2}$ and $\mathrm{CO}_{2}$ partial pressures for internal atmospheres relarespectively (Alleyne and Hagenmaier, 2000; or candelilla wax to the formulations. Off- tive to package atmosphere (Bai et al., 1990), these results suggested that the off-flavor developed because either internal $\mathrm{CO}_{2}$ exceeded 7-9 $\mathrm{kPa}, \mathrm{O}_{2}$ declined to 5-7 $\mathrm{kPa}$, or both.

In this research, we developed several edible and shiny coatings from alternative materials, observed how they affected internal gases, flavor compounds, and subsequently the quality of the coated apples, in an effort to find alternative coatings to shellac. The alternative materials included zein and starch, which are food ingredients with a wholesome image; polyvinyl acetate, which gives high gloss and is an approved food additive (Hagenmaier and Grohmann, 1999); carnauba wax, a natural plant wax; and a natural complex polysaccharide. Zein coatings have been used on candy, dried fruit, nuts, and meats (Baker et al. 1994). Zein also was evaluated on tomatoes resulting in a modified internal atmosphere, color change, inhibition of weight loss, and delayed softening (Park, 1991). Carnauba wax has been used commercially to coat apple, and does not discolor, but has less gloss than shellac. Preliminary experiments showed that application of carnauba coatings resulted in less modification of the internal atmosphere in coated fruit than did shellac, and was more effective in preventing weight loss. Polyvinyl acetate-coated apples had higher internal $\mathrm{O}_{2}$ partial pressures and less alcohol accumulation in fruit compared with shellac (Hagenmaier and Grohmann, 1999).

\section{Material and Methods}

'Delicious' apples (Malus $\times$ domestica Borkh.) were stored in commercial CA ( $1 \mathrm{kPa}$ for both $\mathrm{O}_{2}$ and $\mathrm{CO}_{2}$ at $0.5^{\circ} \mathrm{C}$ and $90 \%$ to $95 \%$ $\mathrm{RH}$ ) in Washington State for 4-5 months, then transported to Florida in a refrigerated truck in Mar. 2000. Uniform (180-210 g) defect-free fruit were equilibrated at room temperature $\left(25^{\circ} \mathrm{C}\right)$ for $24 \mathrm{~h}$, prior to application of coatings. Coatings were applied manually, using $0.5 \mathrm{~mL} /$ fruit, spread evenly over the fruit surface (surface area of $\approx 200 \mathrm{~cm}^{2}$ ) using latex gloved hands. This resulted in a coating thickness of $\approx 25 \mu \mathrm{m}$ when wet, which becomes thinner as the coating dries. Each fruit was inspected for complete coverage. Instead of coating, water was used for control fruit. A pilot-plant scale conveyor dryer (Central Florida Sales and Service, Auburndale, Fla.) was used to dry fruit (including controls) at $50{ }^{\circ} \mathrm{C}$ for $5 \mathrm{~min}$. All fruit (except those processed for initial, day 0 samples) were stored at $2{ }^{\circ} \mathrm{C}$ for 2 weeks, then transferred to $21{ }^{\circ} \mathrm{C}$ for a further 2 weeks, to simulate marketing conditions.

The treatments included experimental zein-, starch-, polyvinyl acetate (PVA)-, and carnauba-polysaccharide (CPS)-based formulations, as well as commercial carnauba- (Natural Shine TM 8000; EcoScience, Orlando, Fla.), and shellac-based (Apple Wax 55; EcoScience) coatings and uncoated controls. The main components of the experimental formulations (expressed as percentage by weight) were: 1) zein ( $8 \%$ defatted zein, $8 \%$ propylene glycol, $25 \%$ isopropanol, $25 \%$ etha- 
nol and 34\% water; 2) starch [11.7\% potato starch (amylogum CLS; Avebe, Princeton, N.J.), 3.1\% tapioca dextrin (K4484; National Starch and Chemical Co., Bridgewater, N.J.), $3.1 \%$ citric acid, $0.8 \%$ malic acid, $0.6 \%$ whey protein isolate (Bipro; Davisco Foods, Le Sueur, Minn.), $0.8 \%$ glycerin, $10 \%$ isopropanol and $70 \%$ water]; and 3) PVA [20\% polyvinyl acetate (Union Carbide, Danbury, Conn.), $2.2 \%$ citric acid, $0.8 \%$ propylene glycol, $57 \%$ isopropanol, and $20 \%$ water]. The CPS was donated by $\mathrm{CH}_{2} \mathrm{O}$ (Seattle, Wash.) for which the exact components are proprietary.

Gloss, internal $\mathrm{O}_{2}$ and $\mathrm{CO}_{2}$ partial pressure, weight loss, and flesh firmness were measured on 10 replicate fruit per treatment. Sugar, acid, and volatiles were determined using three composite replicates of three fruit each. Measurements were conducted initially (day of treatment), after 2 weeks of storage at $2{ }^{\circ} \mathrm{C}$, and after removal from chilled storage plus a 2 weeks marketing period at $21^{\circ} \mathrm{C}$. Initial measurements were taken one day after coating treatment to be sure that the coatings had completely dried.

Fruit surface gloss was measured using a micro-TRI-gloss reflectometer (BYKGardner, Silver Spring, Md.) equipped with a shield having a circular 19-mm-diameter aperture (Hagenmaier and Baker, 1994), and expressed as gloss units (GU) at an angle of $60^{\circ}$. Ten measurements were made per fruit. The same fruit were used initially and at the end of the storage and marketing periods for gloss measurements.

Flesh firmness was assessed with a penetrometer (FT 327; McCormick, Facchini, Alfonsine, Italy), equipped with an 11.1-mmdiameter cylindrical plunger. Two measurements were obtained per fruit from opposite sides where 16-mm-diameter peel discs were removed.

Samples for internal gas were obtained from the core cavity of fruit under submerged conditions (Alleyne and Hagenmaier, 2000). The $\mathrm{CO}_{2}$ and $\mathrm{O}_{2}$ partial pressures were analyzed using a gas chromatograph (HP 5890A; Hewlett-Packard, Avondale, Pa.) equipped with a thermal conductivity detector.

For weight loss determination, fruit were individually weighed initially and at the end of the storage and end of the marketing periods.

Sucrose, glucose, and fructose were analyzed using a HPLC system (Perkin Elmer Series 410, Norwalk, Conn.) (Baldwin et al., 1991; Bett et al., 2000). Fruit were blended using a commercial blender (model 31BL92; New Hartford, Conn.) with equivalent water (weight : volume). The homogenate was kept at $-20{ }^{\circ} \mathrm{C}$ prior to analysis. Homogenate was thawed under running tap water and was added to $80 \%$ ethanol, blended for $30 \mathrm{~min}$, and vacuum-filtered through Whatman No. 4 filter paper. The resulting extract was passed through a C-18 Sep Pak (Waters/Millipore, Milford, Mass.) and a $0.45-\mathrm{m}$ millipore filter. The filtered extract was analyzed using a Waters Sugar Pak column at $90{ }^{\circ} \mathrm{C}$, with a mobile phase of $100 \mu \mathrm{M}$ ethylenediamine tetraacetic acid disodium-calcium salt (Ca EDTA), flow rate of $0.5 \mathrm{~mL} / \mathrm{min}$, and a Perkin Elmer LC-25 Refractive Index detector. Sucrose equivalents (SE) were used to show the relative sweetness, with coefficients of sucrose, glucose and fructose as 1, 0.74, and 1.73 respectively (Koehler and Kays, 1991).

For titratable acidity (TA) analysis, homogenates were titrated to $\mathrm{pH} 8.1$ with 0.1 $\mathrm{N} \mathrm{NaOH}$, and the acidity was calculated as malic acid on weight basis ( $\mathrm{g} / 100 \mathrm{~g}$ ) (Jones and Scott, 1984).

For volatile analysis, 50-g apple slices (core tissue removed) were homogenized with 25 $\mathrm{mL}$ deionized water and $25 \mathrm{~mL}$ saturated $\mathrm{NaCl}$ solution. Two $\mathrm{mL}$ of homogenate was transferred into a 6-mL vial sealed with a crimp-top and Teflon-silicone septum, flash frozen in liquid nitrogen, and stored at $-80{ }^{\circ} \mathrm{C}$ prior to analysis. For GC analysis, sample vials were thawed under running tap water, heated rapidly to $80^{\circ} \mathrm{C}$ and incubated for $15 \mathrm{~min}$ by a Perkin Elmer HS-6 headspace sampler heating block before the headspace sample was injected into the GC. The analysis was carried out using a gas chromatograph (Perkin Elmer model 8500 ) equipped with a $0.53 \mathrm{~mm} \times 30 \mathrm{~m}$ polar stabilwax capillary column $(1.0-\mu \mathrm{m}$ film thickness; Restek, Bellefonte, Pa.) and a flame ionization detector. Oven temperature was held $40^{\circ} \mathrm{C}$ for $6 \mathrm{~min}$, then raised to $180^{\circ} \mathrm{C}$ at a rate of $6{ }^{\circ} \mathrm{C} / \mathrm{min}$. The compounds were identified by comparison of retention times with those of authenticated standards and by enrichment of apple homogenate with authentic compounds. Concentrations were calculated by using regression equations, determined by injecting five different concentrations of each standard to obtain a peak height calibration curve as described by NisperosCarriedo et al. (1990). Identification of volatiles were periodically checked by spiking homogenate with standards. Volatile components that are abundant, or that have been reported to have significance for apple or other fruit flavors (Mattheis et al., 1995) were analyzed including: ethanol, ethyl acetate, ethyl butyrate, butyl acetate, 2-methylbutyl acetate, and hexyl acetate.

PROC GLM of SAS Version 8 (SAS Institute, Cary, N.C.) was used for analysis of variance (SAS Institute, 1999). Mean separation was determined by the Scheffe's test.

\section{Results and Discussion}

Uncoated fruit had low gloss with 3.7 gloss units (GU) initially, that subsequently decreased to $2.7 \mathrm{GU}$ at the end of the total 4-week experiment (Fig. 1). Shellac-coated fruit had an initial gloss up to $11.3 \mathrm{GU}$, decreased to $10.1 \mathrm{GU}$ after 2 weeks of storage at $2{ }^{\circ} \mathrm{C}$, and further decreased to $7.3 \mathrm{GU}$ in the following 2 week marketing period at $21^{\circ} \mathrm{C}$. Since 'Delicious' apples with $6 \mathrm{GU}$ were shiny to the eye, the fruit coated by shellac maintained adequate gloss, even at the end of the marketing period. Starch- and carnauba-coated fruit showed high initial gloss values similar to shellac, while PVA-, zein-, and CPS-coated fruit showed moderate initial gloss (7.5-8.8 GU). The gloss of all coatings decreased during storage, but remained higher than the uncoated control. Since gloss decreased more when the initial value was higher, there were no significant differences among the different coating treatments at the end of 2 weeks storage at $2{ }^{\circ} \mathrm{C}$ and 2 weeks marketing at $21^{\circ} \mathrm{C}$ (5.9-7.3 GU) (Fig. 1). All the coatings maintained substantial shine after the simulated marketing period (limit of noticeable shine is around 6.0 GU).

Internal (core) $\mathrm{O}_{2}$ and $\mathrm{CO}_{2}$ partial pressures in uncoated fruits at the end of 2 weeks storage $\left(2^{\circ} \mathrm{C}\right)$ were 20.1 and $1.1 \mathrm{kPa}$, respectively, and after 2 weeks at $21^{\circ} \mathrm{C}, 18.1$ and 2.8 $\mathrm{kPa}$, respectively (Table 1). In coated fruits, more modification of the internal atmosphere occurred. Internal gas partial pressures of fruit coated by shellac were $9.0 \mathrm{kPaO}_{2}$ and $10.1 \mathrm{kPa}$ $\mathrm{CO}_{2}$ at the end of the 4-week experiment. The

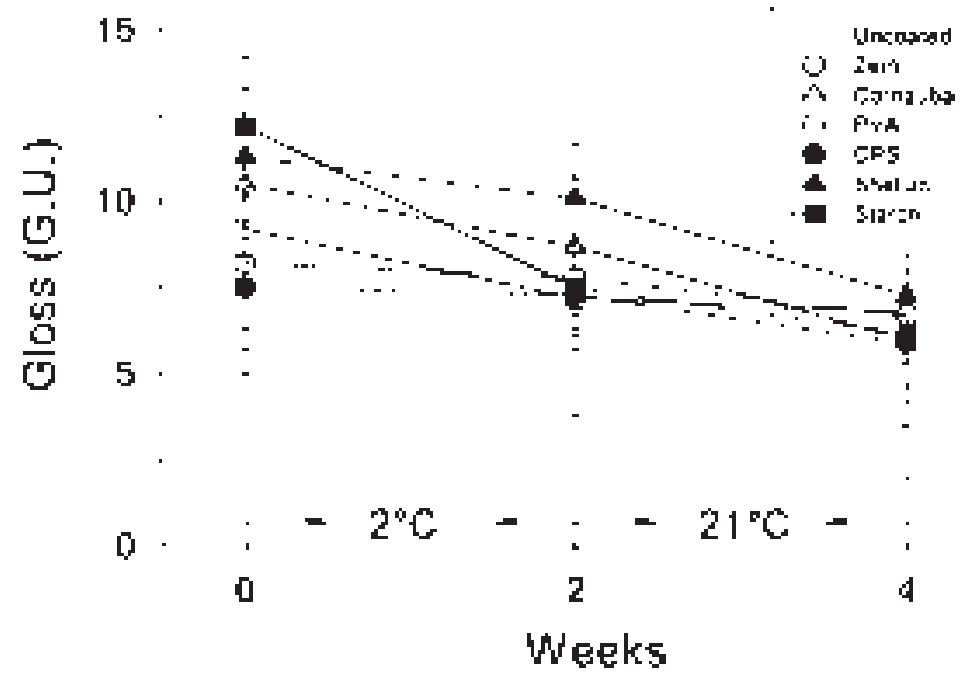

Fig. 1. Gloss of apples coated with each of six coating formulations or uncoated during storage for 2 weeks at $2{ }^{\circ} \mathrm{C}$ followed by 2 weeks at $21{ }^{\circ} \mathrm{C}$. 
internal $\mathrm{O}_{2}$ and $\mathrm{CO}_{2}$ partial pressures created by the starch coating was similar to that created by shellac. However, zein, PVA, and carnauba showed moderate partial pressures of 11.4-14.6 $\mathrm{kPa} \mathrm{O}$, and 6.3-7.4 $\mathrm{kPa} \mathrm{CO}_{2}$. The CPS coating resulted in relatively low values for both internal $\mathrm{O}_{2}(6.0 \mathrm{kPa})$ and $\mathrm{CO}_{2}$ $(5.9 \mathrm{kPa})$.

The recommended CA storage conditions for 'Delicious' apple in the United States are $1-3 \mathrm{kPa} \mathrm{O}_{2}$ and 0 to $5 \mathrm{kPa} \mathrm{CO}_{2}$ at 0 to $3{ }^{\circ} \mathrm{C}$ (Thompson, 1996 and industry sources). The upper $\mathrm{CO}_{2}$ limit of atmosphere is $5 \mathrm{kPa}$ for most apple cultivars, beyond which injury will occur (Watkins, 2000). Conversely, the $\mathrm{O}_{2}$ limit is near $1.5 \mathrm{kPa}$, below which anaerobic respiration can occur (Beaudry, 2000; Gran and Beaudry, 1993). Yearsley et al. (1996, 1997a) reported that the internal lower oxygen limits (LOL) of 'Cox's Orange Pippin' and 'Braeburn' apple were lower than $2 \mathrm{kPa}$, and that temperatures from 0 and $28{ }^{\circ} \mathrm{C}$ did not affect the LOL, although LOL increased slightly at $32{ }^{\circ} \mathrm{C}$. Elevated $\mathrm{CO}_{2}$ within $8 \mathrm{kPa}$ did not affect LOL in both of the apple varieties mentioned above at $20{ }^{\circ} \mathrm{C}$ and affected LOL only slightly at $0{ }^{\circ} \mathrm{C}$ (Yearsley et al., 1997b). However, higher $\mathrm{CO}_{2}$ often leads a lower LOL (Beaudry, 1993). In this work, the high levels of $\mathrm{CO}_{2}$ observed in shellac and starch coated fruits ( 10.1 and $11.3 \mathrm{kPa}$, respectively) could be injurious to the fruit, although the marketing period is relatively short in duration. Zein, PVA, carnauba, and CPS coatings resulted in lower levels of $\mathrm{CO}_{2}$ (5.9-7.4 $\mathrm{kPa}$ ) compared to shellac and starch. None of the internal $\mathrm{O}_{2}$ levels in coated fruit were low enough to cause anaerobic respiration. However, moderate $\mathrm{O}_{2}$ with a slightly high $\mathrm{CO}_{2}$, such as the combination of $6.0 \mathrm{kPa} \mathrm{O}_{2}$ and 5.9 $\mathrm{kPaCO}$ in CPS coating, might cause anaerobic metabolism.

CPS-coated apples had low $\mathrm{O}_{2}$ and $\mathrm{CO}_{2}$ partial pressures that were quite different from apples with other coatings. Unlike other coatings, for which the internal $\mathrm{O}_{2}$ and $\mathrm{CO}_{2}$ pressures, when added together, amounted to $\approx 18-21 \mathrm{kPa}$, this sum for CPS was only 14 $\mathrm{kPa}$ at $2{ }^{\circ} \mathrm{C}$ and decreased to $12 \mathrm{kPa}$ after being removed to $21^{\circ} \mathrm{C}$ (Table 1). Also, the internal $\mathrm{CO}_{2}$ at a given value of internal $\mathrm{O}_{2}$ was much lower for CPS than for the other coatings (Fig. 2). These observations suggest that the CPS coating tended to block pores in the fruit more than other coating treatments. The rationale for this conclusion follows.

If the dominant pathway for gas exchange between fruit and atmosphere is by permeation through intact portions of the skin, and if the respiratory quotient is near unity, then the $\mathrm{CO}_{2}$ pressure difference across the fruit skin is expected to be roughly $1 / 3$ of the $\mathrm{O}_{2}$ pressure difference because $\mathrm{CO}_{2}$ permeabilities tend to be about three times $\mathrm{O}_{2}$ permeabilities (Banks et al., 1993; Comyn, 1985; Stannet 1985). Thus, for example, if internal $\mathrm{CO}_{2}$ is $5 \mathrm{kPa}$ and gas exchange is purely by permeation, the expected internal $\mathrm{O}_{2}$ concentration would be $\approx 6 \mathrm{kPa}(15 \mathrm{kPa}$ below ambient $)$. If, on the other hand, all gas exchange is by diffusion through open pores, then at equal flux rates, the $\mathrm{CO}_{2}$
Table 1. Internal $\mathrm{O}_{2}$ and $\mathrm{CO}_{2}$ partial pressures of 'Delicious' apples coated with each of 6 formulations or uncoated, and kept at $2{ }^{\circ} \mathrm{C}$ for 2 weeks followed by $21^{\circ} \mathrm{C}$ for 2 weeks ${ }^{2}$

\begin{tabular}{llcccc}
\hline \hline & \multicolumn{2}{c}{ Week 2} & & \multicolumn{2}{c}{ Week 4} \\
\cline { 2 - 3 } \cline { 5 - 6 } Treatment & $\mathrm{O}_{2}(\mathrm{kPa})$ & $\mathrm{CO}_{2}(\mathrm{kPa})$ & & $\mathrm{O}_{2}(\mathrm{kPa})$ & $\mathrm{CO}_{2}(\mathrm{kPa})$ \\
\hline Uncoated & $20.1 \mathrm{a}^{\mathrm{y}}$ & $1.1 \mathrm{c}$ & & $18.1 \mathrm{a}$ & $2.8 \mathrm{c}$ \\
Zein & $17.7 \mathrm{~b}$ & $3.6 \mathrm{~b}$ & & $14.6 \mathrm{~b}$ & $6.5 \mathrm{~b}$ \\
Carnauba & $14.8 \mathrm{c}$ & $4.6 \mathrm{~b}$ & & $14.5 \mathrm{~b}$ & $6.3 \mathrm{~b}$ \\
PVA & $17.1 \mathrm{~b}$ & $3.6 \mathrm{~b}$ & & $11.4 \mathrm{c}$ & $7.4 \mathrm{~b}$ \\
CPS & $10.3 \mathrm{~d}$ & $4.6 \mathrm{~b}$ & & $6.0 \mathrm{~d}$ & $5.9 \mathrm{~b}$ \\
Shellac & $11.8 \mathrm{~cd}$ & $5.9 \mathrm{a}$ & & $9.0 \mathrm{c}$ & $10.1 \mathrm{a}$ \\
Starch & $13.5 \mathrm{c}$ & $4.6 \mathrm{~b}$ & & $9.9 \mathrm{c}$ & $11.3 \mathrm{a}$ \\
\hline
\end{tabular}

${ }^{2}$ Initial (week 0) partial pressures at $5{ }^{\circ} \mathrm{C}: 20.0 \mathrm{kPa} \mathrm{O}$ and $1.8 \mathrm{kPa} \mathrm{CO}_{2}$.

${ }^{y}$ Mean value $(\mathrm{n}=10)$ in same column that are not followed by the same letter show significant difference $(P<0.05)$. pressure difference would be expected to be $\approx 30 \%$ greater than the that of $\mathrm{O}_{2}$, because its diffusion constant in air is that much lower than that of $\mathrm{O}_{2}$ (Weast, 1988). For all coatings save CPS, the internal $\mathrm{CO}_{2}$ rose by about the same amount that $\mathrm{O}_{2}$ was lowered (thus resulting in the same total for internal $\mathrm{CO}_{2}$ and $\mathrm{O}_{2}$ pressures). This suggests that the gas exchange was partly by permeation and partly by diffusion. For CPS, the internal $\mathrm{O}_{2}$ fell by much more than the $\mathrm{CO}_{2}$ increased, which is what would be expected if less of the gas were exchanged through holes, thus the conclusion that this coating blocked pores (stomates, lenticels, stem and blossom scars). Meanwhile, the other coatings must not have entered into and blocked all pores as effectively as did the CPS coating. This is dependent on coating characteristics such as viscosity and surface tension as well as the peel anatomy of the fruit (Hagenmaier and Baker, 1993). Future research is warranted to understand how coating properties affect ability of coatings to block pores on fruit surfaces, and how percentage of pore blockage affects fruit internal atmosphere.

Weight loss of uncoated fruit was $2.1 \%$ after 4 weeks of storage $\left(2\right.$ weeks at $2{ }^{\circ} \mathrm{C}+2$ weeks at $21^{\circ} \mathrm{C}$ ). The CPS coating was the least effective in inhibiting weight loss (2.2\%), while carnauba wax was the most effective $(1.3 \%)$, although the differences were not great. Other coatings showed intermediate weight loss control of $1.7 \%$ to $1.8 \%$ (Table 2). Weight loss is mainly caused by evaporation of water from the fruit. Coating, as an additional barrier to the peel, inhibited water loss (except for CPS). It has been reported (Hatfield and Knee, 1988; Maguire et al., 2000) that $3 \%$ to $5 \%$ loss of weight can cause shriveling in apples. In this work, weight loss was below $2.2 \%$, and no shrinkage was observed in any treatment. However, water loss can also cause softening of the flesh, ripening, and senescence, through ethylene production and other metabolic $\mathrm{O}_{2}$ and $\mathrm{CO}_{2}$ through the coatings did not show strong relationships.

Initial firmness (force of resistance) of flesh was 65 N. Firmness decreased slowly at $2{ }^{\circ} \mathrm{C}$ and faster at $21{ }^{\circ} \mathrm{C}$. After the 4 week storage period, the uncoated fruit averaged firmness values of $37 \mathrm{~N}$ (Table 2). All of the coated fruits maintained firmness values of 44 N or greater. Generally, the coating treatments that resulted in higher internal $\mathrm{CO}_{2}$ levels, lower internal $\mathrm{O}_{2}$ levels, or both (Table 1), also changes. Water evaporation and diffusion of

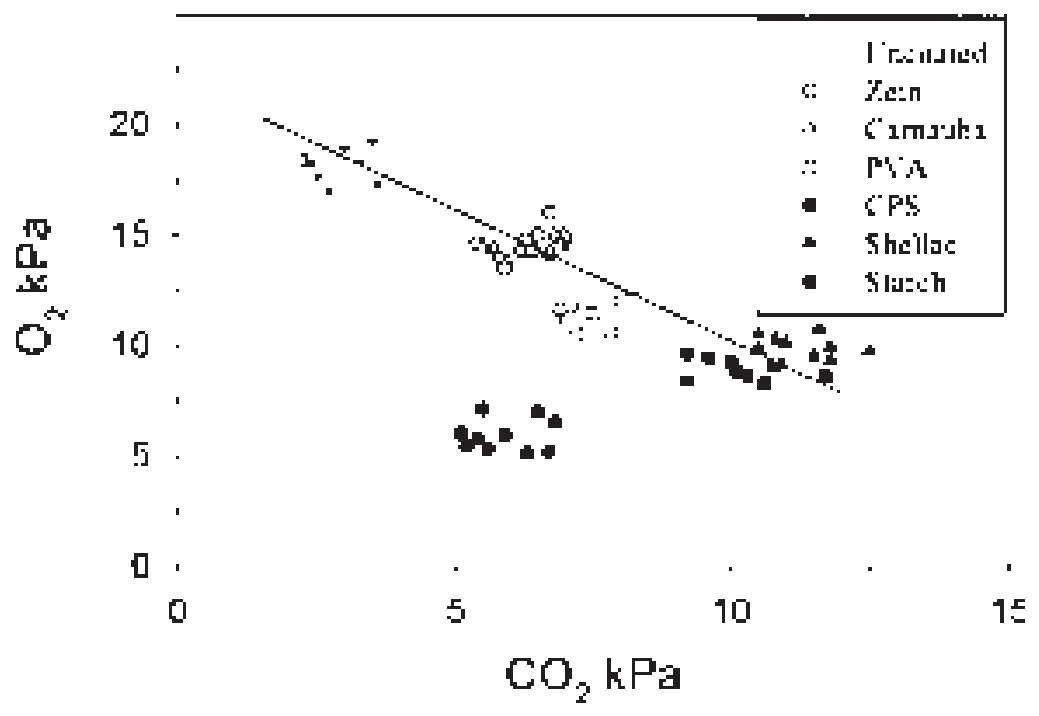

Fig. 2. Relationship between internal $\mathrm{O}_{2}$ and $\mathrm{CO}_{2}$ of 'Delicious' apples coated with each of six coating formulations or uncoated, held for 2 weeks at $2{ }^{\circ} \mathrm{C}$ followed by 2 weeks at $21^{\circ} \mathrm{C}$. The linear regression line is for formulations other than the carnauba-polysaccharide (CPS), with a slope of -1.1 and an intercept of $21.0\left(r^{2}=0.908\right)$. 
Table 2. Weight loss, firmness, sucrose equivalents (SE), titratable acidity (TA) contents, and sugar-acid ratio of 'Delicious' apples coated with each of 6 formulations or uncoated, and held at $2{ }^{\circ} \mathrm{C}$ for 2 weeks followed by $21^{\circ} \mathrm{C}$ for 2 weeks.

\begin{tabular}{lccccc}
\hline \hline Treatment & $\begin{array}{c}\text { Wt loss } \\
(\mathrm{kPa})\end{array}$ & $\begin{array}{c}\text { Firmness } \\
(\mathrm{N})\end{array}$ & SE & $\begin{array}{c}\text { TA } \\
(\% \mathrm{wt})\end{array}$ & $\begin{array}{c}\text { SE/TA } \\
\times 100\end{array}$ \\
\hline Uncoated & $2.1 \mathrm{a}^{\mathrm{z}}$ & $37 \mathrm{c}$ & $16.7 \mathrm{a}$ & $0.18 \mathrm{~b}$ & $92.8 \mathrm{a}$ \\
Zein & $1.8 \mathrm{ab}$ & $44 \mathrm{~b}$ & $16.5 \mathrm{a}$ & $0.20 \mathrm{ab}$ & $82.5 \mathrm{~b}$ \\
Carnauba & $1.3 \mathrm{c}$ & $46 \mathrm{~b}$ & $16.5 \mathrm{a}$ & $0.20 \mathrm{ab}$ & $82.5 \mathrm{~b}$ \\
PVA & $1.7 \mathrm{~b}$ & $46 \mathrm{~b}$ & $16.2 \mathrm{a}$ & $0.19 \mathrm{ab}$ & $85.3 \mathrm{~b}$ \\
CPS & $2.2 \mathrm{a}$ & $51 \mathrm{a}$ & $16.0 \mathrm{a}$ & $0.23 \mathrm{a}$ & $69.6 \mathrm{c}$ \\
Shellac & $1.7 \mathrm{~b}$ & $52 \mathrm{a}$ & $15.7 \mathrm{a}$ & $0.23 \mathrm{a}$ & $68.3 \mathrm{c}$ \\
Starch & $1.8 \mathrm{ab}$ & $54 \mathrm{a}$ & $15.9 \mathrm{a}$ & $0.24 \mathrm{a}$ & $66.2 \mathrm{c}$
\end{tabular}

${ }^{2}$ Mean value ( $n=10$ for weight loss and firmness; $n=3$ for SE, TA, and SE/TA in same column that are not followed by the same letter show significant difference $(P<0.05)$

resulted in fruits that maintained greater firmness values compared to other treatments, and the same is true for all coated fruit compared to uncoated controls. 'Starking Delicious' apples with firmness values lower than $44 \mathrm{~N}$ acquire a mealy texture (Ueda et al., 1993).

Coated fruits generally exhibited higher TA than controls, with CPS, starch, and shellac being significantly different (Table 2). Although there were no significant differences in SE, SE/TA ratios of coated fruit were significantly lower values than that of uncoated controls. Coatings that resulted in higher internal $\mathrm{CO}_{2}$, lower internal $\mathrm{O}_{2}$, or both, had the fruit with the lowest SE/TA ratios. The average contents of individual sugars were $7.1 \%$ fructose, $3.3 \%$ glucose, and $1.4 \%$ sucrose, for which there were no significant differences among treatments (data not shown). Hulme and Rhodes (1971) reported that taste in pome fruit is principally based on sugaracid balance. The ratio of SE/TA indicates that all of the coating treatments delayed ripening and the deterioration of flavor by preventing loss of acidity.

Ethanol accumulated in most coated fruit at $2{ }^{\circ} \mathrm{C}$, except for those coated with zein, for which the ethanol content was similar to that in uncoated control fruit (Table 3). This occurred even though internal $\mathrm{O}_{2}$ levels were $>10 \mathrm{kPa}$, which should not have induced anaerobic respiration. Ethanol may have accumulated within the coating barrier, depending on coating permeability properties. Ethanol levels were $\approx 40,25,20,5,5$, and 1 times higher than that of controls for starch-, shellac-, CPS-, PVA-, carnauba-, and zein-coated fruits, respectively. Ethanol levels declined substantially after storage at $21{ }^{\circ} \mathrm{C}$ for two weeks in fruit from most coating treatments, but increased in control and zein- coated fruits. This may indicate an alteration of respiratory metabolism, using accumulated ethanol as substrate for ester production. Ueda et al. (1993) reported that the ethanol evolution of 'Starking Delicious' apple, stored in MA packaging with 5-9 $\mathrm{kPa} \mathrm{O}_{2}$ and 5 to $6 \mathrm{kPa}$ $\mathrm{CO}_{2}$, increased shortly after packaging and decreased gradually after 4 weeks storage at $8{ }^{\circ} \mathrm{C}$, while control fruit remained low in ethanol evolution at first, and increased as senescence proceeded. Ethyl esters (for example ethyl acetate and to a lesser extent, ethyl butyrate) showed a similar pattern to ethanol. However, the 'Delicious' apple aroma components butyl acetate, 2-methylbutyl acetate, and hexyl acetate generally increased when the fruits were removed from $2{ }^{\circ} \mathrm{C}$ to $21{ }^{\circ} \mathrm{C}$. The concentrations of these aroma compounds, however, were generally lower in coated fruit than in controls (except for hexyl acetate), in contrast to ethanol and
Table 3. Concentration of volatile components $(\mu \mathrm{g} / 100 \mathrm{~g})$ in 'Delicious' apples coated with each of six formulations or uncoated, and kept at $2^{\circ} \mathrm{C}$ for 2 weeks followed by $21^{\circ} \mathrm{C}$ for 2 weeks

\begin{tabular}{|c|c|c|c|c|c|c|}
\hline & \multicolumn{2}{|c|}{ Ethanol } & \multicolumn{2}{|c|}{ Ethyl acetate } & \multicolumn{2}{|c|}{ Ethyl butyrate } \\
\hline & Week 2 & Week 4 & Week 2 & Week 4 & Week 2 & Week 4 \\
\hline Uncoated & $102 \mathrm{f}^{\mathrm{z}}$ & 169 ef & $1 \mathrm{f}$ & $6 \mathrm{ef}$ & $1 \mathrm{~d}$ & $9 a$ \\
\hline Zein & $127 \mathrm{ef}$ & $243 \mathrm{e}$ & $3 \mathrm{f}$ & 9 de & $1 \mathrm{~d}$ & $11 \mathrm{a}$ \\
\hline Carnauba & $545 \mathrm{~cd}$ & $114 \mathrm{~g}$ & $47 \mathrm{c}$ & $3 \mathrm{f}$ & $4 c$ & $3 \mathrm{~cd}$ \\
\hline PVA & $552 \mathrm{c}$ & $535 \mathrm{~cd}$ & $3 \mathrm{f}$ & $3 \mathrm{f}$ & $1 \mathrm{~d}$ & $4 \mathrm{c}$ \\
\hline CPS & 1996 b & 305 de & $151 \mathrm{~b}$ & 9 de & $5 \mathrm{bc}$ & $2 \mathrm{~d}$ \\
\hline Shellac & $2552 \mathrm{~b}$ & 349 de & $164 \mathrm{~b}$ & $13 \mathrm{~d}$ & $11 \mathrm{a}$ & $4 \mathrm{c}$ \\
\hline \multirow[t]{3}{*}{ Starch } & $4652 \mathrm{a}$ & $19 \mathrm{f}$ & $294 \mathrm{a}$ & $13 \mathrm{~d}$ & $9 a b$ & $6 \mathrm{~b}$ \\
\hline & \multicolumn{2}{|c|}{ Butyl acetate } & \multicolumn{2}{|c|}{ 2-methylbutyl acetate } & \multicolumn{2}{|c|}{ Hexyl acetate } \\
\hline & Week 2 & $\overline{\text { Week } 4}$ & Week 2 & Week 4 & Week 2 & Week 4 \\
\hline Uncoated & $16 \mathrm{~d}$ & $61 \mathrm{a}$ & $43 \mathrm{bc}$ & $67 \mathrm{a}$ & $1 \mathrm{~d}$ & $2 \mathrm{c}$ \\
\hline Zein & $14 \mathrm{~d}$ & $49 \mathrm{~b}$ & $34 \mathrm{c}$ & $50 \mathrm{~b}$ & $1 \mathrm{~d}$ & $5 \mathrm{a}$ \\
\hline Carnauba & $13 \mathrm{~d}$ & $52 \mathrm{~b}$ & $27 \mathrm{~cd}$ & $53 \mathrm{~b}$ & $2 \mathrm{c}$ & $4 a b$ \\
\hline PVA & $16 \mathrm{~d}$ & $45 \mathrm{~b}$ & $30 \mathrm{c}$ & $51 \mathrm{~b}$ & $3 a b c$ & $3 \mathrm{~b}$ \\
\hline CPS & $12 \mathrm{~d}$ & $38 \mathrm{c}$ & $24 \mathrm{~cd}$ & $41 \mathrm{bc}$ & $1 \mathrm{~cd}$ & $1 \mathrm{~cd}$ \\
\hline Shellac & $14 \mathrm{~d}$ & $48 \mathrm{~b}$ & $24 \mathrm{~cd}$ & $45 \mathrm{~b}$ & $2 \mathrm{c}$ & $3 \mathrm{~b}$ \\
\hline Starch & $12 \mathrm{~d}$ & $51 \mathrm{~b}$ & $17 \mathrm{~d}$ & $54 \mathrm{~b}$ & $1 \mathrm{~d}$ & $4 \mathrm{ab}$ \\
\hline
\end{tabular}

${ }^{\mathrm{z}}$ Mean value $(\mathrm{n}=3)$ in same compontent that are not followed by the same letter show significant difference $(P<0.05)$. the ethyl esters. In banana, melon and strawberry fruit, the ester production, in conjunction to alcohol moieties, strongly reflected the alcohol content in the fruit (Ueda et al., 1992). Perhaps a similar pattern occurs in apple with acyl CoAs being competitively metabolized to certain ethyl esters rather than other esters. This was observed by Berger and Drawert (1984) for apples stored in ethanol vapor, and by Mattheis et al. (1991) for apples stored in an anaerobic environment $\left(0.05 \mathrm{kPa} \mathrm{O}_{2}\right)$ which accumulated ethanol and ethyl esters.

\section{Conclusion}

'Delicious' apples coated with zein-, starch-, carnauba-, CPS-, and PVA-based formulations showed intermediate initial gloss compared to shellac-coated and uncoated fruit, and ultimately a similar level of gloss compared with fruit coated with shellac, after storage for two weeks at $2{ }^{\circ} \mathrm{C}$ followed by two weeks at $21{ }^{\circ} \mathrm{C}$. Shellac- and starch-coated fruit showed the greatest deterioration of gloss during storage compared to the other coating treatments, partially due to the fact that they had the highest initial gloss readings. The formulations of zein, carnauba, CPS and PVA provided more optimal internal gas levels in term of less $\mathrm{CO}_{2}$ accumulation, and maintained good quality. The three coatings resulting in the lowest $\mathrm{O}_{2}$ levels, retarded firmness, gave the highest TA and the lowest SE/TA (indicating delayed ripening) but also accumulated the most ethanol and ethyl acetate. This is interesting since $\mathrm{O}_{2}$ levels were not low enough to expect inhibition of ethylene production (and subsequent retardation of ripening). Ethanol has been shown to inhibit ethylene synthesis in tomatoes (Kelly and Saltveit, 1998) and these coated fruit had high ethanol levels. However, $\mathrm{O}_{2}$ levels were not low enough to expect induction of anaerobic ethanol production. One explanation is that $\mathrm{CO}_{2}$ levels may have induced fermentation, as has been suggested for blueberry, although levels of $\mathrm{CO}_{2}$ were higher in that study (Beaudry, 1993). Alternatively, perhaps ethanol accumulated within the coating barrier.

\section{Literature Cited}

Alleyne, V. and R.D. Hagenmaier. 2000. Candelllashellac: An alternative formulation for coating apples. HortScience 35:691-693.

Bai, J.H., Y. Ueda, T. Iwata, and H. Yoshioka. 1990. Effect of polyethylene packaging on volatiles productions of apple fruits with reference to gas concentrations in fruits. J. Jpn. Soc. Hort. Sci. 59(Suppl 2):714-715.

Baldwin, E.A. 1994. Edible coatings for fresh fruits and vegetables: past, present, and future, p. 25 64. In: J.M. Krochta, E.A Baldwin, and M.O. Nisperos-Carriedo (eds.). Edible coatings and films to improve food quality. Technomic Publishing Co., Lancaster $\mathrm{Pa}$.

Baldwin, E.A., M.O. Nisperos-Carriedo, and M.G. Moshonas. 1991. Quantitative analysis of flavor and other volatiles for certain constituents of two tomato cultivars during ripening. J. Amer. Soc. Hort. Sci. 116:265-269.

Baker, R.A., E.A. Baldwin, and M.O. NisperosCarriedo. 1994. Edible coatings and films for 
processed foods, p. 89-104. In: J.M. Krochta, E.ABaldwin, and M.O. Nisperos-Carriedo (eds.). Edible coatings and films to improve food quality. Technomic Publishing Co., Lancaster Pa.

Banks, N.H., B.K. Dadzie, and D.J. Clcland. 1993. Reducing gas exchange of fruits with surface coatings. Postharvest Biol. Technol. 3:269-284

Beaudry, R.M. 1993. Effect of carbon dioxide partial pressure on blueberry fruit respiration and respiratory quotient. Postharvest Biol. Technol. 3:249-258.

Beaudry, R.M. 2000. Responses of horticultural commodities to low oxygen: Limits to the expanded use of modified atmosphere packaging. HortTechnology 10:491-500.

Berger, R.G. and F. Drawert. 1984. Changes in the composition of volatiles by post-harvest application of alcohols to Red Delicious apples. J. Sci. Food Agr. 35:1318-1325.

Bett, K.L., D.A. Ingram, C.C. Grimm, S.W. Lloyd, A.M. Spanier, J.M. Miller, K.C. Gross, E.A. Baldwin, and B.T. Vinyard. 2000. Flavor of fresh-cut Gala apples in barrier film packaging as affected by storage time. J. Food Qual. 24:141156.

Comyn, J. 1985. Polymer permeability, p. 283-317. Elsevier, London, New York.

Gran, C.D. and R.M. Beaudry. 1993. Determination of the low oxygen limit for several commercial apple cultivars by respiratory quotient breakpoint. Postharvest Biol. Technol. 3:259-267.

Hagenmaier, R.D. and R.A. Baker. 1993. Reduction in gas exchange of citrus fruit by wax coatings. J. Agr. Food Chem. 41:283-287.

Hagenmaier, R.D. and R.A. Baker. 1994. Internal gases, ethanol content and gloss of citrus fruit coated with polyethylene wax, carnauba wax, shellac or resin at different application levels. Proc. Fla. State Hort. Soc. 107:261-265.

Hagenmaier, R.D. and K. Grohmann. 1999. Polyvinyl acetate as a high-gloss edible coating. J.
Food Sci. 64:1064-1067.

Hagenmaier, R.D. and P.E. Shaw. 1992. Gas permeability of fruit coating waxes. J. Amer. Soc. Hort. Sci. 117:105-109.

Hatfield, S.G.S. and M. Knee. 1988. Effects of water loss on apple in storage. Intl. J. Food Sci. Technol. 23:575-583.

Hulme, A.C. and M.J.C. Rhodes. 1971. Pome fruits, p. 333-436. In: A.C. Hulme (ed.). The biochemistry of fruits and their products, Vol. 2. Academic, London, New York.

Jones, R.A. and S.L Scott. 1984. Genetic potential to improve tomato flavor in commercial F1 hybrids. J. Amer. Soc. Hort. Sci. 109:318-321.

Kelly, M.O. and M.E. Saltveit. 1998. Effect of endogenously synthesized and exogenously applied ethanol on tomato fruit ripening. Plant Physiol. 88:1136-1140.

Koehler, P.E. and S.J. Kays. 1991. Sweet potato flavor: Quantitative and qualitative assessment of optimum sweetness. J. Food Qual. 14:241249.

Maguire, K.M., N.H. Banks, A. Lang, and I.L. Gordon. 2000. Harvest date, cultivar, orchard, and tree effects on water vapor permeance in apples. J. Amer. Soc. Hort. Sci. 125: 100-104.

Mattheis, J.P., D.A. Buchanan, and J.K. Fellman. 1991. Change in apple fruit volatiles after storage in atmospheres inducing anaerobic metabolism. J. Agr. Food Chem. 39:1602-1605.

Mattheis, J.P., D.A. Buchanan, and J.K. Fellman. 1995. Volatile compound production by Bisbee Delicious apples after sequential atmosphere storage. J. Agr. Food Chem. 43:194-199.

Nisperos-Carriedo, M.O., P.E. Shaw, and E.A. Baldwin. 1990. Changes in volatile flavor components in 'Pineapple' orange juice as influenced by the application of lipid and composite films. J. Agr. Food Chem. 38:1382-1387.

Park, H.J. 1991. Edible coatings for fruits and vegetables: Determination of gas diffusivities, pre- diction of internal gas composition and effects of the coating on shelf life. PhD Diss., Univ. of Georgia.

SAS Institute. 1999. SAS/STAT User's Guide, Version 8. SAS Inst., Cary, N.C.

Stannett, V.T. 1985. The permeability of plastic films and coated papers to gases and vapors. Tappi J. 68:22-26.

Thompson, A.K. 1996. Postharvest technology of fruit and vegetables. Blackwell Science, London. p. 253-259.

Ueda, Y., A. Tsuda, J.H. Bai, N. Fujishita, and K. Chachin. 1992. Characteristic pattern of aroma ester formation from banana, melon, and strawberry with reference to the substrate specificity of ester synthetase and alcohol contents in pulp. Nippon Shokuhin Kogyo Gakkaishi. 39:183187.

Ueda, Y., J. Bai, and H. Yoshioka. 1993. Effects of polyethylene packaging on flavor retention and volatile production of Starking Delicious apple. J. Jpn. Soc. Hort. Sci. 62:207-213.

Watkins, C.B. 2000. Responses of horticultural commodities to high carbon dioxide as related to modified atmosphere packaging. HortTechnology 10:501-506.

Weast, R.C. 1988. CRC Handbook of Chemistry and Physics, $69^{\text {th }}$ Ed., p. F48. CRC Press, Boca Raton, Fla.

Yearsley, C.W., N.H. Banks, S. Ganesh, and D.J. Cleland. 1996. Determination of lower oxygen limits for apple fruit. Postharvest Biol. Technol. 8:95-109.

Yearsley, C.W., N.H. Banks, and S. Ganesh. 1997a. Temperature effects on the internal lower oxygen limits of apple fruit. Postharvest Biol. Technol. 11:73-83.

Yearsley, C.W., N.H. Banks, and S. Ganesh. 1997b. Effect of carbon dioxide on the internal lower oxygen limits of apple fruit. Postharvest Biol. Technol. 12:1-13. 